\title{
FACTORS AFFECTING THE CHOICE OF CONTRACEPTIVE METHOD AMONG FAMILY PLANNING ACCEPTORS AT LILIBA, KUPANG, EAST NUSA TENGGARA
}

\author{
Margaritha Talak \\ Masters Program of Public Health, Faculty of Public Health, \\ Universitas Nusa Cendana, East Nusa Tenggara
}

\begin{abstract}
Background: Contraceptive use can prevent maternal death by prevent undesired events including unintended pregnancy, unsafe abortion, and sexually transmitted diseases including HIV. Contraceptive methods differ in effectiveness and a typical-use. This study aimed to examine the factors affecting the choice of contraceptive method among family planning acceptors at Liliba, in Kupang, East Nusa Tenggara.

Subjects and Method: This was a cross sectional study conducted at Liliba Auxiliary Community Health Center, in Kupang, East Nusa Tenggara. A total of 100 family planning acceptors were selected for this study. The dependent variable was the choice of contraceptive method. The independent variables were health counseling and husband support. The data were obtained by a questionnaire. The data were analyzed by a multiple logistic regression.

Results: The choice of contraceptive method increased with health counseling (OR= $5.01 ; 95 \% \mathrm{CI}=1.68$ to $14.97 ; \mathrm{p}=0.004)$ and husband support $(\mathrm{OR}=0.19 ; 95 \% \mathrm{CI}=0.05$ to $0.65 ; \mathrm{p}=0.008)$.

Conclusion: The choice of contraceptive method increases with health counseling and husband support.
\end{abstract}

Keywords: choice of contraceptive method, health counseling, husband support.

\section{Correspondence:}

Margaritha Talak. Masters Program of Public Health, Faculty of Public Health, Universitas Nusa Cendana, Kupang, East Nusa Tenggara. Email: magetalak3o@gmail.com.

Mobile: 082236224080.

The $6^{\text {th }}$ International Conference on Public Health

Best Western Premier Hotel, Solo, Indonesia, October 23-24, 2019 | 229

https://doi.org/10.26911/the6thicph.03.87 